\title{
Affect Theory with Literature and Art: Between and Beyond
}

RePRESENTATION

TEORÍA DEL AFECTO EN LA LITERATURA Y EL ARTE: EN LA REPRESENTACIÓN Y MÁS ALLÁ DE

LA REPRESENTACIÓN

Sandra Moyano Ariza

The Graduate Center (CUNY); smoyano@gradcenter.cuny.edu

\begin{tabular}{|c|c|}
\hline Historia editorial & bstract \\
\hline Recibido: 01-12-2017 & \multirow{9}{*}{$\begin{array}{l}\text { This paper maps the intersection of affect theory with literature and art through } \\
\text { the revision of the question of representation. I argue that affect theory reinvigor- } \\
\text { ates the problematic of representation by turning it into a debate about mediation, } \\
\text { producing two main critical gestures when in contact with literary and artworks. } \\
\text { On the one hand, scholarship has stayed "between representation" by taking affect } \\
\text { as excessive of cognitive processes in order to analyze and expand how affect in- } \\
\text { fluences our representations of these processes, both when doing literary and art } \\
\text { criticism, and when elaborating epistemological paradigms. On the other, theory } \\
\text { has also stepped "beyond representation" by looking at affect as an autonomous } \\
\text { entity in mediation whose capacities affect and surpass human cognition. In treat- } \\
\text { ing affect as a new capacious entity, critical concerns revolve around ontological } \\
\text { questions, and they prioritize what affect is and does to bodies more than what it } \\
\text { means. }\end{array}$} \\
\hline Primera revisión: 27-03-2019 & \\
\hline Aceptado: 01-10-2019 & \\
\hline Publicado: 10-07-2020 & \\
\hline Keywords & \\
\hline Affect theory & \\
\hline Literature & \\
\hline & \\
\hline Representation & \\
\hline
\end{tabular}

\section{Resumen}

Palabras clave

Teoría del Afecto

Literatura

Arte

Representación
Este artículo mapea la intersección de la teoría del afecto con la literatura y el arte mediante la revisión de la cuestión de la representación. En el artículo mantengo que la teoría del afecto revitaliza esta problemática, transformándola en un debate sobre mediación y produciendo dos nuevos gestos teóricos al entrar en contacto con obras literarias y artísticas. Por un lado, parte de esta literatura se ha quedado "en la representación," ya que se acerca al afecto como un exceso de procesos cognitivos emocionales para analizar y expandir su conocimiento e influencia en las representaciones de estos procesos afectivos, tanto en la teoría literaria y artística como en la elaboración de paradigmas epistemológicos. Por otro lado, la teoría también ha intentado ir "más allá de la representación," investigando el afecto como una tercera entidad autónoma en procesos de mediación con capacidades para afectar y traspasar la cognición humana. Al tratar el afecto como una nueva entidad capaz de subjetividad en sí misma, las preocupaciones críticas que informan este gesto giran en torno a cuestiones ontológicas, y priorizan lo que el afecto es y hace a los cuerpos más que lo que significa.

\section{Introduction}

Since literature and art are always enlivened by emotions, it is often difficult to mark the beginning of literary and art criticism's intersection with affect. As a result, the point of departure of this intersection will be the two seminal texts that mark the foundations of affect theory: Eve Sedgwick and Adam Frank's "Shame in the Cyber- 
netic Fold," and Brian Massumi's "The Autonomy of Affect," both published in $1995^{1}$. My cut in this intersection thus understands affect as distinct from feeling. Works that do not acknowledge this distinction in their contact with literature and art criticism have stayed out of this intersection. As such, this paper leaves aside the vast amount of literary criticism linked to historical analysis of sympathy and sentimentality in North-American Literature (see, for example, Bell, 2000; Hendler, 2001; Bown, 2007; and Ablow, 2008), as well as scholarship belonging to discussions of affective criticism and reader-response theory (see, for example, Thrailkill, 2007; and Felski, 2015 for the former, and Ablow, 2010; and Canning and Whiteley, 2017 for the latter). Additionally, since both the literature on affect theory and the literature located in this intersection have mostly been published in English, the works discussed belong almost in its entirety to anglophone criticism ${ }^{2}$.

In order to address the contribution of affect theory to literature and art and vice versa, I believe it is crucial to revisit the question of representation and its crisis, which has been central in theorizing literary and art concerns, especially in post-structuralist and deconstructivist informed theories. As Claire Colebrook (2005) points out, the epistemological concern with representation in modern philosophy was taken as the "condition of finitude" of the subject (p. 2), by which the human gives up access to things-in-themselves (Kant, 1790/1987) in order to think the representational limits of knowledge. Regarding post-structuralism and deconstruction more specifically, these limits were embodied in a generalized critique of "all forms of "presence" (Thomassen, 2017), or in other words, a belief that everything that is present will only be constituted through or in representation: language, meaning, consciousness, identity, structures, and so on. Acknowledging this limit allows the subject to acquire freedom of self-determination and autonomy (Colebrook, 2005), but also conditions human experience as it becomes always mediated, in turn limiting the "degree to which the world can be thought" (Somers-Hall, 2012, p. 56).

Maurice Blanchot, probably one of the greatest thinkers of this limit, unpacks this conundrum of representation in The Space of Literature (1955/1989):

What can be said of it? What exactly is this interiority of the exterior, this extension within us where "the infinite," as Rilke says at the time of the Capri experience, "penetrates so intimately that it is as though the shining stars rested lightly in his breast"? Can we truly accede to this space? And how can we? For consciousness is our destiny; we cannot leave it; and in it

\footnotetext{
Ali Lara and Giazú Enciso Domínguez (2013) elaborate on the development of these texts as the foundations for a geneology of affect theory in "El giro afectivo" (p. 103-104).

2 For literature in Spanish on this intersection, see, for example, Macón, 2014; Macón and Solana, 2015; and Paszkiewicz, 2016.
} 
we are never in space but in the vis-à-vis of representation where we are always busy, moreover -busy acting, doing and possessing. (pp. 136-7)

Blanchot's passage does not merely point to "the truth of language as absence," as Steven Shaviro (1990) argues, but also to "the continuing insistence of that which is always absent from the truth. The event of death is neither the motor of truth in language, nor the repressed truth of language, but rather that which language must first foreclose in order for there to be such a thing as truth at all” (pp. 18-9).

When thinking about this inaccessible space in the reading and analysis of literature and art, the limit of representation is doubled. As representations, literature and art are both the image that allows us to reflect back on an already mediated reality they become representative of a certain history, event, or practice-; and at the same time the constructed, misstated representations that can never achieve the status of the real. This is representation's inherent conundrum with literary and art objects: while they are used to decipher impenetrable aspects of human experience, they are relegated to a form of life that is heuristically flawed in relation to the subject.

The production of this inaccessible space in representation as the limiting condition of being in post-structuralism and deconstruction becomes the site of contention in affect theory. Affect complicates and expands the possibilities of the debate on representation not by resolving the space in between but by bringing it back to life. Most importantly, affect theory turns the crisis of representation into a debate about mediation, thus problematizing the understanding of the in-between as a mere reflection, on the one hand, as well as the nature of mediation itself, on the other. Gilles Deleuze and Félix Guattari draw emphasis on this twofold structure of mediation when elaborating on their notion of affect in What is Philosophy? (1991/1996):

Affects are no longer feelings or affections; they go beyond the strength of those who undergo them. Sensations, percepts, and affects are beings whose validity lies in themselves and exceeds any lived. They could be said to exist in the absence of man because man, as he is caught in stone, on the canvas, or by words, is himself a compound of percepts and affects. The work of art is a being of sensation and nothing else: it exists in itself. (p. 164)

This quote sheds light on the two main aspects that affect discloses regarding representation as mediation. On the one hand, when affect is undergone, bodies (human and nonhuman) are affected by this affect. Affect mediates between two objects (or an assemblage of objects) producing an encounter, consequently impacting the bodies at the ends of it. On the other, since affect affects, it also emerges as a being whose 
"autonomous" capacities, to use Massumi's (2002) words, go beyond connecting two ends, in turn declaring agency in this encounter. Thus, as Melissa Gregg and Gregory Seigworth (2010) claim, affect arises in an "in-between-ness" and "resides as accumulative beside-ness" (p. 2). Affect does not cease to exist after mediating two ends but continues to circulate as autonomous capacity among bodies. This has directly impacted the conditions of representation, both in terms of the limits of the representational, and in terms of the nature of representation itself. While post-structuralism and deconstruction acknowledged the conundrum of representation, with affect theory the space of representation expands and allows theory to reflect on this pre-cognitive affect affecting bodies as well as on the nature of representation itself as autonomous mediation.

Therefore, departing from what I believe is affect theory's main contribution to literary and art criticism, I propose to approach the authors in this intersection by looking at the ways they have dealt with representation after accessing this double movement revealed in the structure of affect. As I see it, this double movement produces two main gestures in criticism. On the one hand, affect theory provides a richer theoretical corpus to deal with the gap produced in representation. Affect here offers a lexicon to expand on the analyses of pre-cognitive processes that lead to emotion in order to open a space to think how these processes are represented in literature and artworks, or to contribute as representations of current epistemological problems. On the other, affect also emerges as a realm that questions the nature of representation as mediation. By focusing on affect as autonomous, this realm casts attention to the ontological status of mediation, problematizing the relation subject-object as well as the status of affect itself. In other words, when dealing with the conundrum of representation, the first group stands "between representation," while the second moves "beyond representation.”

I define the affect of the theorists of the first group, that is, of those that stay between representation, affect as "excess." These authors understand affect as being somehow of "excessive" nature. My use of excess in this context is intended in two important ways. First, these works locate their theories as continuation ${ }^{3}$ of the poststructuralist and deconstructivist concern with excess understood as that which escapes subjectivity, cognition, definition, and therefore, representation ${ }^{4}$. And second, because in taking affect as excessive they understand affect as linked to cognitive pro-

\footnotetext{
3 Some revisions of affect have located the theory directly in response to, or as expansion of, post-structuralist concerns (see Hemmings, 2005; and Hogan, 2016).

4 "Excess" in post-structuralism was firstly conceptualized against structuralist perspectives of the subject, using excess as "plurality" of meanings, discourses, and power relations that inform the subject but to some extent escapes them. Later, Derrida would delve into the concept in Of Grammatology (1976).
} 
cesses, their analyses always foreground the bodies, subjective processes, and representational paradigms to which affects are attached or from which they emerge. For the authors in this group, affect becomes relevant because it is excess of something conscious, representational which nevertheless continues to define the human.

The affect of the second group, of those who step beyond representation, focuses on affect as "capacity." In focusing on affect's autonomous properties, the theories of this group revolve around ontological concerns of affect itself, and they prioritize what affect is and does more than what it means. By focusing on the properties of affect as a new capacious entity in these relations, affect is able to render art and literary works as objects with agentic capacities, and not as representations that are dependent on cognitive processes. By going beyond representation, they problematize the paradigms that pose linguistic and material media as mere tools and account for affect beyond a human-centered paradigm.

Finally, even though there are some overlapping definitions of affect between the two groups, I think it is worth pointing out the elements in common in each group when using affect to approach representation. Roughly speaking, it could be argued that the first group will be mostly informed by Silvan Tomkins (1962) as read in Sedgwick and Frank (1995), while the second group will be adamant to Deleuze and Guattari’s (1991/1996) affect via Massumi's (1995) interpretation. However, some authors in the first group are working on Deleuze's (1990/1992) reading of Spinozian affect, which they still take on to expand epistemologies of affect within the limits of representation and the subject. In this sense, it is worth noting that most of the authors in both groups respond to some extent to the originary definition of affect by Baruch Spinoza (1677/1985), which understands that affect is both relational and capable, as noted in the quote above. In addition, the second group might be engaging more with Deleuze and Guattari's (1991/1996) definition of "apersonal affect" when thinking about works of art and their affect separate from the subject, which is different from

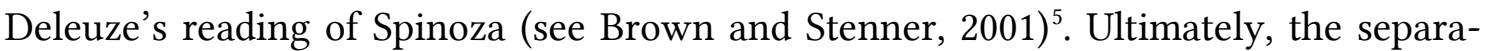
tion of both genealogies is for the sake of emphasizing the commonalities within each group's affect as they produce two different approaches to representation in literature and art.

\footnotetext{
Thanks to the anonymous reviewers of this paper for pointing out the two different understandings of affect in Deleuze (1990/1992) and Deleuze in Guattari (1991/1996) so that the definitions of affect in the two groups could be clearer.
} 


\section{Between representation: affect as excess}

The authors included in this section correspond to the approach to the intersection that I have described as staying "between representation." In this sense, they understand affect, from different angles, as tied to (or as the route to) feeling so that their theorizations foreground the bodies to which affects are attached and from which they emerge. In understanding affect as excess, these authors respond to the weariness of the linguistic turn in post-structuralism and deconstruction, as well as provide new alternatives to their critical concerns. For example, in biologistic and psychological fashion, Sedgwick and Frank's (1995) text responds to the "heuristic habits" of a structuralist critique that "reproduces and popularizes" (p. 497) binary structures. The excess of their affect provides the "site for resistance" (Sedgwick and Frank, 1995, p. 503) that "enables learning, development, continuity, differentiation" (p. 510).

The authors in this group constitute the "following generation," to use Catherine Malabou's (2012) terms, both as the "descendants, the inheritors, the sons and daughters," and the generation "engendering, [...] constituting the following itself" (pp. 20-1). In other words, in reengendering, reshaping again this inheritance, the authors gathered here envision the new possibilities of the previous theory. Scholarship located most clearly in this genealogy is Rei Terada's Feeling in Theory (2001), which attempts to theorize emotions after the "death of the subject" from a deconstructivist angle. She reads the nonsubjectivism of Jacques Derrida and Paul de Man as bearing the possibility of theorizing emotions beyond the subject. Most precisely, for Terada it is getting rid of the subject that constitutes the condition of possibility of a turn to emotion.

In this scenario, the theorists of affect as excess approach the issue of representation in literary and art objects following two different perspectives. On the one hand, I distinguish a subgroup in literary and art criticism which uses affect theory as a lens to attend to the different affective and cognitive registers of feeling in literary and artworks. Affect theory as a lens uses taxonomies of feeling and affect to fill in the gap of analysis, always evaluating the feelings portrayed in the work as holding meaning. This scholarship speaks of affect and emotion as they are represented in literary texts and art, and it aligns with more traditional modes of lens or textual analysis. On the other hand, the second subgroup of theorists turn to literature and art's representation of these registers to trace the histories of feeling and collective affects in our social and political contexts. Here cultural studies and other disciplines in the social sciences use aesthetic works to represent their critical concerns and contribute to epistemological endeavor. Thus, while the first group is concerned with how authors represent, the second group turns to representation to put it at the service of epistemology. 


\section{Affect as lens: describing excess}

As Ben Highmore (2010) puts it, literature and art are the aesthetic terrain that covers both "'the vehement passions' (fear, grief, rapture, and so on), and the minor and major aspects and emotions (humiliation, shame, envy, irritation, anxiety, disdain, surprise, and so forth)" (2010, p. 121). A vast array of scholarship in literary studies uses affect theory as a theoretical lens to expand on the interpretative analyses of this aesthetic terrain. In this sense, this perspective is more aligned with Sedgwick and Frank's (1995) demand for taxonomies to be able to attend to affective registers. Affect theory has provided literary criticism with a method and a vocabulary to speak about intensified forms of emotion and affect in literary works. This, in turn, has propelled the revision of literary periods and corpuses through the lens of affect theory in the recent years (see Taylor, 2015; Bailey and DiGangi, 2017; Figlerowicz, 2017; and Marculescu and Morand Métivier, 2018). Additionally, affect has also become an essential component for new methodologies in recent trends of textual criticism (see Anker and Felski, 2017; Wehrs and Blake, 2017).

Charles Altieri's The Particulars of Rapture. An Aesthetics of Affect (2003) is, together with the already mentioned Terada (2001), an early example of work in the intersection that provides a framework to speak about affect and emotion as represented in literature and art. He focuses on affective states that are not related to strong cognitive emotions, which according to him are the ones by which literature acquires its status. ${ }^{6}$ This is Altieri's (2003) affect: the "range of states open to self-reflection that are too subtle or transient to have much to do with cognition or with rational appraisal" (p. 5). By revisiting the anti-cartesian philosophical tradition on affects and emotions, he puts forward a representational theory that can account for "expressivity" while doing away with literary criticism's "vicious tendency to overread for 'meaning' while underreading the specific modes of affective engagement presented by works of art" (p. 3).

While Altieri (2003) outlines new "bodies of grammar" to account for a more complex reality of psychological emotions represented and invoked by literary and artworks, his representational theory remains limited to the emotions that are expressed by the characters of the novels he analyzes, and how our identifications with those emotions impact "how we reflect upon the values involved in our various ways of experiencing the world" (p. 5). His analysis contemplates affective registers only in

\footnotetext{
${ }^{6}$ While Altieri's proposal does have a response-theory component informing his account of affective values, I will focus on his analysis primarily in terms of what he thinks affect theory can provide as representational modes for enriching literary criticism.
} 
the moment of identification between the reader and the characters. For him, "this is what brings the aesthetic into the existential" (Altieri, 2003, pp. 23-4).

This understanding of feeling as being contained in the subject has been disputed in literary criticism recently (see Houser, 2014; Smith, 2011, and 2015; and Vermeulen, 2015). For example, Rachel Greenwald Smith's Affect and American Literature in the Age of Neoliberalism (2015) pushes back against the idea of the "affective hypothesis," or this "privileging of the 'single human being' as the location of feeling in fiction" (Smith, 2011, pp. 425-6). Smith locates her discussion of contemporary literature at the "seeping edge" where affect and emotion, described as "impersonal" and "personal" feelings, respectively, abide. For Smith (2011), literature is the art form that more directly complicates that edge: "affectively exciting insofar as aesthetics stimulate sensory responses, but linguistically based and therefore inevitably codifying, literature stimulates and codes relentlessly" (p. 431).

In her study, affect is rather understood as the "effect" (Smith, 2015, p. 19) that literary works transmit when working and producing that edge. As a result, this approach foregrounds affect's "corporeal and therefore impersonal site of registration on the one hand and the particularities of its social, cultural, and historical interpretation on the other" (Smith, 2011, p. 429). Ultimately, her critique of the affective hypothesis envisions an understanding of affect in literature that exceeds affect between the reader and the literary work. In fact, Smith's claim to study affect as "impersonal site of registration" in literary criticism is more in line with the next group, which focuses in the analysis of collective affect to contribute to sociopolitical critique. ${ }^{7}$

\section{Collective affect: capturing excess for sociopolitical critique}

The authors in this group explore the ways affect theory allows for new critical forms to articulate the preconscious circulation of affects partaking in neoliberalist knowledge production. They believe in "affect theory's potential as a means of questioning, diagnosing, subverting, [and] reclaiming the culture we live in" (Figlerowicz, 2012, p. 13). Their works are very much influenced by queer approaches to literature and other art forms; in fact, we could say that some of the works in this section also partake in a larger intersection of queer theory, critical race theory, affect theory, and literary and cultural studies (see Cvetkovich, 2003; Love, 2007; Eng, 2010; Chen, 2012; or Ahern 2019). The theorists of collective affect turn to literature to represent affect's dynamics and untangle its effects in relation to the social as well as the knowledge we produce to understand it.

\footnotetext{
7 Smith claims that her work is deeply inspired by Sianne Ngai's work (Smith, 2015, p. 18), who is a main figure in the collective feelings section.
} 
Sara Ahmed (2004) and Sianne Ngai (2005) can be said to have become the prevalent theorists of the positive and negative affects that construct current politics of emotion in late-capitalist and neoliberal contexts. While Ahmed $(2004,2010)$ analyzes the "stickiness" of affective encounters between objects and subjects that impose a certain form of felt happiness, Ngai (2005) focuses on negative emotions in literature to trace the more general "aesthetics of complex and highly particularized feelings such as envy, irritation, anxiety, stuplimity, paranoia, and disgust” (p. 32). Using affect theory to approach literature's excessive negative affects, which she defines as an "animatedness" of feeling that exceeds both "the reader's emotional response to a text or [...] the text's internal representations of feeling" (p. 30), Ngai (2005) traces the move from the affect between the reader and the text to its translation into the critique of a sociality of ugly feelings.

Ngai's excess in Ugly Feelings (2005) is embodied in her analysis of "tone" as "a system of exchange based on a highly codified feeling that is continually reproduced and circulated even as it cannot be subjectively felt" (p. 76-77). The power of circulation of tone as asubjective and negative affect in literary works proves that this intangibility of affect is as fundamentally "'social' as the institutions and collective practices, [...] and as 'material' as the linguistic signs and significations" (Ngai, 2005, p. 25) that construct both individual and collective subjectivities. In her most recent book, Our Aesthetic Categories. Zany, Cute, Interesting (2012), Ngai will target even more seemingly intangible affects that build our contemporary aesthetic categories, which, despite their apparent triviality and uncertain form, or because of it, have become the more profitable categories in our sociopolitical contexts.

Similarly, the theorists that conform the Public Feelings project, with groups in Texas, Chicago, and New York, attempt to assemble a "sociology of accidental encounters" (Figlerowicz, 2012, p. 3) which can respond critically and politically to the targeting of affect in contemporary life. The critical exercises of Kathleen Stewart (2007), Lauren Berlant (2011), Ann Cvetkovich (2012), and others, open a space to analyze "liberalism and neoliberalism in affective terms-to take on the vocabularies of tolerance, diversity, and multiculturalism as connected to certain affects or structures of feeling that are inadequate to, or that too conveniently package and manage, the messy legacies of history" (Cvetkovich, 2007, p. 465).

In stark contrast with the approach to affect as lens, the Public Feelings group's use of literature and art does not see "what happens to aesthetically mediated characters as equivalent to what happens to people," but rather claim that through the "affective scenarios of these works and discourses we can discern claims about the situation of contemporary life" (Berlant, 2011, p. 9). Therefore, they offer a different treat- 
ment of the "affective hypothesis," one that complicates the lines that separate the intimate from the public ${ }^{8}$, and the individual from the social. This is part of the excess that escapes bodies: one that adds to cognitive processes and also partakes in the construction of the social, emphasizing the role of the political in affective emanations.

Lauren Berlant's Cruel Optimism (2011) provides a significant example of how this social and political analyses reconceptualize the understanding of affect in the social sciences and the humanities. Her affect is excessive in the sense that it problematizes (and exceeds) notions of history as well as temporality. Her critical endeavor is committed to capturing the present in both its capacity to be volatile and historical at the same time. For Berlant (2011), the "present is perceived, first, affectively" and, as such, "if the present is not at first an object but a mediated affect, it is also a thing that is sensed and under constant revision, a temporal genre whose conventions emerge from the personal and public filtering of the situations and events that are happening" (p. 4). With this task in mind, her turning to aesthetic objects provides evidence of "a proprioceptive history," to capture, that is, to represent, "norms of bodily adjustment as key to grasping the circulation of the present as a historical and affective sense" (Berlant, 2011, p. 20).

For the last example of this section, I want to bring in recent scholarship in contemporary art which has similarly explored the possibilities of alternative forms of collective subjectivity and spectatorship through affect theory. Cristina Albu complicates the political capacity of affect in her book Mirror Affect. Seeing Self, Observing Others in Contemporary Art (2016) ${ }^{9}$. She analyzes contemporary participatory art to examine "the contingent relations spurred among art participants by reflective art practices, which epitomize the growing uncertainty and complexity of the world we share with others" (Albu, 2016, p. 4). In contrast to the prevalence of individualistic, contemplative modernist modes of art viewing, these participatory artworks focus on social relations and use mirroring acts to "encapsulate our attachment to the potential for change, whether personal or social, without offering any guarantee of its felicitous realization" (Albu, 2016, p. 5).

Like Public Feelings's attention to the sociality and temporality of affective relations and human and nonhuman assemblages, Albu's (2016) study of affective intersubjectivity in artworks by Olafur Eliasson (2003), Anish Kappor (2001), or Doug

\footnotetext{
A good example of the blurring between the intimate and public is Lauren Berlant's notion of the "intimate public," which she has theorized in depth in The Queen of America Goes to Washington City: Essays on Sex and Citizenship (1997) and The Female Complaint (2008). See also Berlant and Greenwald, 2012.

9 Despite making a case framed around the autonomy of the object and its capacity, Albu is in this section because her work proposes a representational criticism of participatory artworks. Even though her framework will rely on Mark Hansen's work, who we will see in the next section, she addresses the art object as creating a space for affects to circulate and give room to the spectators' interpretation and potential for political change.
} 
Aitken (2013) stretches the space of representation through prolonged mirror intervals of exposure, expanding the viewers' sense of time and foregrounding the possibilities (yet not the actualization) of "affective relatedness" (Albu, 2016, p. 261) in the "becoming multiple" with the art object and the spectators (Albu, 2016, p. 173) ${ }^{10}$. As Mark B. Hansen (2006) has argued, whose work Albu uses to ground her analysis, new media art 'transforms framing from an 'objective' condition of the site into a process encompassing site, space, and body, [...] from static, black-boxed technical frame to a dynamic bodily-generated one” (p. 209).

The first section of this paper has attempted to theorize the various critical exercises that have engaged in this intersection by staying between representational processes. Whereas the authors in the subgroup of affect as lens delve into the representations of affective experiences for both the reader and literary characters to expand on psychological and interpretive bodies of affect theory, works within the collective affect group use the Deleuzian logic of assemblage of subjects and objects, affects and feelings, in literature and art to represent the affective logics that shape social life and its dominant epistemologies. Despite having its differences, the scholarship in both subgroups emphasizes the excessive character of affect, and their ultimate goal is to analyze how affect influences our cognitive understanding of these processes, when reading and doing literary criticism, in the former, and when looking for epistemological "paradigms for how best to live on" (Berlant, 2011, p. 3), in the latter. Conversely, before we move onto the next section, it is important to note that locating criticism between representation also implies that their proposals are going to produce a representation of affect. When these authors try to dissect how affect works pre-cognitively to shape our feelings, they implement representation to capture affect's movement ${ }^{11}$. In the next section, we will attend to the theories that speculate about the possibilities of locating critique beyond representation.

\section{Beyond representation: affect as capacity}

If instead of staying in between the conundrum of representation we confront it by trying to step beyond representation, the questions that arise will revolve, first of all, around the authority that we have to claim such a leap. Simon O'Sullivan (2001), thinking art theory beyond representational paradigms, claims: "this world of affects, this universe of forces is our own world seen without the spectacles of subjectivity. But how to remove these spectacles, which are not really spectacles at all but the very

\footnotetext{
${ }^{10}$ See her chapter "Mirror Intervals. Prolonged Encounters with Others" (Albu, 2016, p. 155-202).

${ }^{11}$ Simon O'Sullivan (2006) argues this same thing about systematizing Deleuze's thought: for him, by extracting a method in Deleuze's philosophy, we are trying to "capture its movement," we are representing his thought (p. 3).
} 
condition of our subjectivity?” (p. 128). Similarly, Patricia T. Clough (2008) points out that "without language as method, or meaning as the end, writing the subject-in-affect is in search of itself" (p. 140). Theoretical works that depart from this new problematic are part of the approach to the intersection that I have called beyond representation.

The questions of the theorists in this group are not so much directed at how affect reconfigures or enriches the representation of new critical concerns, but rather how affect's capacities have changed the nature of representation itself, focusing more on mediation as a point of departure which turns the "middle" alive. Therefore, for these theorists, affect's capacities push for an ontological move beyond the discursive that directly demands a rethinking of human subjectivity. If for Blanchot the very impossibility of grasping the truth was the condition of its existence, and therefore our sentence to stay in the realm of representation, the theorists included in this section have taken that impossibility as the condition to legitimate the speculation of such reality (Shaviro, 2009). Consequently, they are not concerned so much with how affect has an impact on consciousness, language, or the representation of feelings, but rather with how the emergence of this realm poses ontological questions about the subjects and objects -and the object's affects- that also exist outside our frameworks of representation.

In this scenario, I have divided these theorists according to two main concerns that arise from studying affect's capacity on an ontological plane. On the one hand, some theorists have concentrated on the possibilities of writing to attend to the outside of representation that affect reveals. This translates into a renewed interest in experimental writing, especially from theorists outside literary and art studies, who consider the act of writing not as a mechanism to represent but as an independent medium that affects, thereby proposing a "non-representational" (Thrift 2007) phenomenology for this particular medium. On the other, scholarship has attempted to provide new theoretical frameworks to examine the object and its affects, refusing to understand their status as representations but engaging with their reality and capacities as independent entities. In directing theory towards the objects' capacity to affect, they provide speculative approaches to the object beyond its signification. While the first group looks at literary mechanisms to reconsider the consequences for human subjectivity of the affective turn, the second group produces theory that leaves space to the art object to pronounce itself.

\section{Writing as capacity}

The theorists in this section foreground questions of methodology and subjectivity in writing affect beyond representation. When affect theory grants us access to a realm 
beyond the cognitive, when technology shows that subjectivity is not so "tightly linked to representation," as Clough (2000) has argued, critique takes a leap "from representation to presentation" (p. 286). The turn to affect along with -or thanks to- new technological advancements bears impact on how academia understands writing after having posed such changes to representation and subjectivity. As Elspeth Probyn (2010) claims, "thinking, writing, and reading are integral to our capacities to affect and to be affected" (p. 77). Affect theory has ignited a momentum for the rethinking of writing and authorship by questioning and getting more attuned with the object's affect, in this case the capacity that the act of writing holds as autonomous agent in the production of knowledge to make something comprehensible.

It is worth noting that this interest in writing as affective has already been tackled, especially in the study of literature (see Riley, 2005; Houen, 2011; and Frank, $2014)^{12}$. However, these studies remain tied to textual interpretation as representations that show how language "does" or "performs" feeling (Houen, 2011, p. 228). Although language in these cases is treated as an entity which can affect us on its own, these exercises have remained within representational frameworks. More than analyzing how language does feeling, then, the authors in this group turn to writing as a medium that can entangle and connect itself with that which escapes consciousness. In this sense, the feminist theorist and physicist Karen Barad (2007, 2012) will talk about the entanglement of matter and meaning as a form of being "in touch" with "world's aliveliness" (2012, p. 207). For her, there is a materiality of thought and theory, both in writing and in physics, which takes part in an onto-epistemology of matter and knowledge (2007). The matter of writing is real as it shows the entanglement of relations that it contributes to produce and develop. Her theory escapes representationalism in the sense that it is embedded in the ontological possibilities that writing materializes: "ontological indeterminacy, a radical openness, an infinity of possibilities, is at the core of mattering" (Barad, 2012, p. 214).

Philip Vannini (2015), following Nigel Thrift (2007), argues that non-representational methodologies are emerging across different disciplines to provide a "more radical solution" to address the "more-than-human, more-than-textual, multisensual worlds” (p. 3). Kathleen Stewart (2015), included in Vannini's volume, considers experimental writing as non-representational methodology, or, as she states, "more than representational" (p. 19). She argues that writing has relational potential beyond meaning to attend to sensory phenomena. With her article "New England Red" (2015),

\footnotetext{
${ }^{12}$ Here it should be acknowledged that the interest in writing and affect has also been extensively covered in psy choanalytical scholarship on affect and language. This signals a larger intersection of psychoanalysis, language, affect theory, and trauma studies that also resorts to literature and art to develop their theories. See, for example, Bennett, 2005; Ball, 2007; Best, 2011; or Richardson, 2016.
} 
Stewart creates "compositional reals" of this color to attend to "the associational register of connections and differences, materials and noumena, the coagulations and diffusions of lines of influence and bits of matter" (p. 21). Here, writing is not only a medium to convey our relation or understanding of a certain object. The interaction of Stewart and red is far from the unidirectional relation described in traditional phenomenology, and less so in hermeneutics; Stewart's (2015) writing awaits and stays "nimble in the effort to keep up with the distributed agencies of what's throwing together and falling apart” (p. 21).

This new approach to writing problematizes the capacity of our methods to access the real, but at the same time acknowledges that it is only through these methods that we can get closer to the real. Ali Lara (2017) has argued that the authors that share this concern use experimental writing as a medium to access the "infra-empiric level," a term coined by Clough (2009), which "allows a rethinking of bodies, matter and life through new encounters with visceral perception and preconscious affect" (Clough, 2009 , p. 44). In her most recent work, Clough (2018) reflects on the use of experimental compositions as a form "to evoke unconscious processes" (p. xxxi). For her, these unconscious processes help devise what she calls the "user unconscious," which can "rethink subjectivity and sociality in the shift from the private and the public to the personal and the networked" (Clough, 2018, p. ix). Clough's register, just as Barad's or Stewart's conceptualization, delegates to experimental writing not only the capacity to make an idea intelligible, but also the capacity to touch with that idea, to experience the other agencies and sensibilities in the becoming with it. It is important to remember, as we move to the second group, that the questioning of paradigms and methodologies, in this case of writing, does not stem from the human's will to attribute agency to the objects outside; but rather the imperative that objects are imposing on humans and human-centered critical systems. It is humans, then, who have to get attuned to what other-than-human entities are doing or claiming.

\section{Speculative capacities}

Because the theorists in this section step beyond representation, their paradigms will always put forward theoretical frameworks that will bear a speculative component (Shaviro 2009). These authors focus on the autonomy of objects and the new phenomenologies that these establish, drawing attention to the affective capacities that objects have as autonomous beings. As such, unlike some of the theorists that stayed between representation, those engaged in speculative endeavors see capacity and affect as emanated from the object, rather than a force that can animate an object (see Bennett, 2010). In this sense, the examples that are compiled in this section tend to fo- 
cus on art more than literature, as the artwork's materiality is able to account for the capacities of affect, as well as to be more attuned with the technologies that have revealed these affects ${ }^{13}$.

Against representational paradigms in art theory, Simon O'Sullivan's Art Encounters with Deleuze and Guattari (2006) proposes a return to aesthetics in Deleuze and Guattari's sense, that is, aesthetics understood as deterritorializing power that can "take us outside our 'selves"” (p. 38). Focusing on art's life as independent from the human's, what he calls the art's "apartness" (O'Sullivan, 2001, p. 125; and 2006, p. 39), O'Sullivan (2006) puts forward a theory of affect that is immanent to art and that steps beyond the discursive to foreground "art's asignifying potential" (p. 38). For him, to "take off the spectacles of subjectivity," then, is to open theory to the understanding of the encounter as a fissure in representation that can break off from the habitual, in turn "reconnect[ing] us with the world, opening us up to the non-human universe that we are part of but typically estranged from" (O'Sullivan, 2006, p. 50). The affective layer of art acts, it's alive, both in the interaction that we establish with the object as well as in the "naming" of the art object itself, by which the object establishes a "principle of internal cohesiveness" (O'Sullivan, 2006, p. 52). Thus, the specificity of art is that which, while not being totally accessible to our experience, allows the subject to see and feel -to be affected by- the materialization of the affective encounter as well as the emerging potentialities of disruption ${ }^{14}$.

Mimi Sheller (2015) has recently put into practice a critique that might very well be included in O'Sullivan's proposal. Looking at interdisciplinary artworks like Teri Rueb's acoustic landscapes, or the mobile locative pieces by the artists LoVid, Sheller (2015) lays out an understanding of interdisciplinary art as one in which bodies are exposed to "enactments of non-representational theories" (p. 137). According to her, by immersing our bodies in non-representational affective experiences, we produce an encounter with the piece that produces both immanent experience and a new alternative mode of "research-creation" (Sheller, 2015, p. 137) embedded in an ontological re-

\footnotetext{
${ }^{13}$ Especially digital art, as we will see with Mark B. Hansen's (2015) example. For accounts that cover specifically affect and digital art, see, for example, Karatzogianni and Kuntsman, 2012; Fritsch and Markussen 2012; or Kwastek, 2013.

${ }^{14}$ O'Sullivan (2006) ends the chapter by acknowledging that our relation to art and art itself will always dwell in between signifying and asignifying realms due to the fact that art operates "through the manipulation of signify ing material” (p. 66). However, O'Sullivan's (2006) reading of Deleuze's affective dimension of art, and more specifically painting -as in his studies of Bacon-, is that it holds the potential to deterritorialize and access "that wildness which is always already underneath these systems" (p. 66). O'Sullivan (2006) concludes that the entanglement of both realms is used by art to be able to pose such (non-representational) disruptions: "We might say then that art's power to deterritorialise, its affective dimension, is actually produced through 'history,' through the utilization and mixture of past forms, past affective assemblages. [...] [Art] utilizes the stuff of the world to go beyond that world" (p. 67). This aspect of Deleuze's theory continues to be central in rethinking philosophical and aesthetic paradigms. See, for example, John Brenkman's treatment of the figure and the figurative, sensation and the sensational in his book Mood and Trope: Rhetoric and Poetics of Affect (2020).
} 
gister. Instead of evaluating an object, we inhabit a new critical practice that has the potential for creating something new. For Sheller, then, research is about a new becoming more than a task of representation of an author's subjectivity.

Lastly, another example of theorizing affect beyond representation has been put forward by Mark B. Hansen's (2015) recent analysis of twenty-first-century media through a rereading of Alfred North Whitehead's philosophy. Hansen $(2004,2006)$ has long been a primary figure in the study of affect and new media, especially with his media theorizations about affect's capacity to impact the body beyond perception, or as he has it, at the "infraperceptual level" of experience. Yet, it is in this more recent take on contemporary media and technologies of data-mining and analytics that he has been able to pose affect not only outside bodily perception but also located in a "worldly sensibility" informing both human and nonhuman experiential processes. For him, twenty-first century media has uncovered worldly sensibility's expanded access to experiential processes beyond human cognition. Thus, twenty-first century media go from just being a medium to unfolding their full capacity, their "inherent or constitutive doubleness: their simultaneous, double operation as both a mode of access onto a domain of worldly sensibility and a contribution to that domain of sensibility" (Hansen, 2015, p. 6).

As I see it, Hansen's (2015) worldly sensibility completely reconfigures classical phenomenology and representational accounts of subjective experience. Hansen (2015) proposes that subjectivity must be conceptualized as being composed of "the operation of a host of multi-scalar processes, some of which seem more 'embodied' (like neural processes), and others more 'enworlded' (like rhythmic synchronization with material events" (p. 3). He will resort to the performance piece Gatherings (2011) by media artist Jordan Crandall, which immerses the spectator in "data-intensive environments" (Crandall in Hansen 2015, p. 251) to show the human's "crucial implication" in the ongoing processes of worldly sensibility. For him, Crandall's piece illustrates "a certain tension between the dispersal of experience elicited by twenty-firstcentury media and the ongoing-and perhaps never more pressing-necessity for a return of and to human-centered attention" (Hansen, 2015, p. 251-252).

It is worth pointing out how complicated it would be to contextualize the speculative work of the theorists above without acknowledging the intellectual relevance of other contemporary theories that have contributed to this ontological turn. I am referring in particular to the philosophical movements of speculative realism and its subgroup Object-Oriented Ontology (OOO), which have defended speculation as a practice for academic endeavor, in turn legitimizing the battleground of affect as an ontological one. For example, Steven Shaviro $(2009,2015)$ and Timothy Morton (2013), both 
literary theorists before engaging in philosophical undertakings, have also looked at literary and art objects to speculate about methodologies beyond representation. In the case of Shaviro (2015), his speculative realism has taken refuge in speculative and science fiction, literary genres that despite having received a lot of attention in posthumanist critique (Hayles, 1999), it is often an overlooked corpus in affect theory. For Shaviro (2015), the literary object acts as a realm of "testable propositions" (p. 8) that allow possible worlds and narratives beyond representation. On the other hand, Morton (2012a) has offered a new way of looking at literary criticism that also acknowledges a pre-established position for the readers by the text itself (p. 42). Morton (2012b) presents an object-oriented approach to poetry and art that foregrounds their aesthetic dimension -the only one that is accessible according to an object-oriented ontology (Harman, 2002; Morton 2013)- as a form of seeing and analyzing how "causality itself operates" (p. 206).

In the second half of this paper, I have attempted to compile some theorists that have engaged in this intersection by trying to speculate beyond representation. Despite focusing on different aspects of this problematic -on authorship and the writing subject, on the one hand; and on the object's material capacities, on the other- the au thors gathered here contribute to the ontological rethinking of critique and method with literary and art objects after the affective turn. Brian Massumi (2015) has called this kind of critical endeavor "immanent critique," which "actively alters conditions of emergence" and "engages becoming, rather than judging what is" (p. 71) ${ }^{15}$. I believe Barad's anti-representationalist, onto-epistemological paradigm, Clough's notion of the infraempiric, or Stewart's compositional reals, for the first group; and O'Sullivan's ethicoaesthetics of affect, Sheller's non-representational embodiment of practices and research-creation, or Hansen's study of worldly sensibility, for the second, are all examples of immanent critique going beyond representation through their ontological understanding of affect as capacious.

\section{Final Remarks}

In this paper I have mapped the intersection of affect theory with literature and art through the revision of the question of representation owing to the fact that this has been a, if not the, central contribution of affect to these disciplines. In doing so, I have traced two main gestures in criticism when in contact with literary and artworks: one that stays between representation, trying to resolve and expand the conundrum by us-

\footnotetext{
${ }^{15}$ Massumi first talks about "immanent critique" in an interview with Joel McKim (2008) while discussing the aesthetic-political events organized by SenseLab, the interdisciplinary group of artists and academics founded by Erin Manning in Montreal. See http://senselab.ca/wp2/, or Manning and Massumi, 2014.
} 
ing affect theory's body of knowledge, and another that attempts to step beyond representation, by speculating about affect itself and posing ontological questions regarding mediation.

As pointed out earlier in the paper, the decision to attribute affect as excess to the former, and affect as capacity to the latter does not presuppose that affect is strictly just one or the other. As Brian Massumi (2002) points out, when there is something captured, it is also the sign that "something has always again escaped," and as such, "something remains unactualized, inseparable from but unassimilable to any particular, functionally anchored perspective. [...] Actually existing, structured things live in and through that which escapes them. Their autonomy is the autonomy of affect" (p. 35). Affect is always both: excess of something else and autonomous in its potentiality.

Therefore, to look at it separately in this paper was aimed at facilitating the understanding of the double movement that affect theory makes impossible to ignore in literary and art criticism in particular, and in critical and cultural theory in general. If affect theory turns the debate of representation into one about mediation, any critical endeavors located at the intersection of affect and another field will always have to acknowledge these two sides and "situate" (Haraway, 1989) their critique before putting themselves at work. I believe that is also true for the rest of the arts that have not been included in this paper, whose intersections have already been explored, and which could potentially benefit from the approach presented here: music and sound studies (Goodman, 2010; Biddle and Thompson, 2013; Kassabian, 2013; Thompson, 2017), theatre (Hurley, 2014), dance and performance (Bleeker, Foley, and Nedelkopoulou, 2015; Lepecki, 2016; Reason and Mølle Lindelof, 2017), or cinema (Shaviro, 2010), for example.

Mapping the encounter of affect theory and literature and art this way contributes to a rethinking of these disciplines in their perspectives regarding representation. While affect has propelled literary and art criticism to reconsider the representational qualities (and the life) of their objects, literary and art objects will keep challenging affect theory's capacity to theorize them without exhausting the representational limits of knowledge.

\section{References}

Ablow, Rachel (2008). Introduction: Victorian Emotions. Victorian Studies, 50(3), 375377. https://doi.org/10.2979/vic.2008.50.3.375

Ablow, Rachel (Ed.). (2010). The Feeling of Reading: Affective Experience and Victorian Literature. Ann Arbor: University of Michigan Press. 
Ahern, Stephen (Ed.). (2019). Affect Theory and Literary Critical Practice: A Feel for the Text. New York: Palgrave Macmillan.

Ahmed, Sarah. (2004). The Cultural Politics of Emotion. New York: Routledge.

Ahmed, Sarah. (2010). The Promise of Happiness. Durham, NC: Duke University Press.

Albu, Cristina. (2016). Mirror Affect. Seeing Self, Observing Others in Contemporary Art. Minneapolis: University of Minnesota Press.

Altieri, Charles. (2003). The Particulars of Rapture. An Aesthetics of Affect. Ithaca, NY: Cornell University Press.

Anker, Elizabeth, \& Felski, Rita (Eds). (2017). Critique and Post-Critique. Cambridge, MA: Duke UP.

Bailey, Amanda, \& DiGangi, Mario (Eds.). (2017). Affect Theory and Early Modern Texts. Politics, Ecologies, and Form. New York: Palgrave Macmillan.

Ball, Karyn (Ed.). (2007). Traumatizing theory; the cultural politics of affect in and beyond psychoanalysis. New York: Other Press.

Barad, Karen. (2007). Meeting the Universe Halfway. Quantum Physics and the Entanglement of Matter and Meaning. Durham, NC: Duke University Press.

Barad, Karen. (2012). On Touching-The Inhuman that Therefore I Am. differences, 23(3), 206-223. https://doi.org/10.1215/10407391-1892943

Bell, Michael. (2000). Sentimentalism, Ethics and the Culture of Feeling. New York: Palgrave Macmillan.

Bennett, Jane. (2010). Vibrant Matter. A Political Ecology of Things. Durham, NC: Duke University Press.

Bennett, Jill. (2005). Empathic Vision: Affect, Trauma, and Contemporary Art. Stanford, CA: Stanford University Press.

Berlant, Lauren. (1997). The Queen of America Goes to Washington City: Essays on Sex and Citizenship. Durham: Duke University Press.

Berlant, Lauren. (2008). The Female Complaint: The Unfinished Business of Sentimentality in American Culture. Durham: Duke University Press.

Berlant, Lauren. (2011). Cruel optimism. Durham, NC: Duke University Press.

Berlant, Lauren, \& Greenwald, Jordan. (2012). Affect in the End Times: A Conversation with Lauren Berlant. Qui Parle: Critical Humanities and Social Sciences, 20(2), 71-89. https://doi.org/10.5250/quiparle.20.2.0071

Best, Susan. (2011). Visualizing Feeling: Affect and the Feminine Avant-garde. New York: Palgrave Macmillan.

Biddle, Ian, \& Thompson, Marie. (2013). Sound, Music, Affect: Theorising Sonic Experience. New York: Bloomsbury Academic \& Professional.

Blanchot, Maurice. (1955/1989). The Space of Literature. (Trans. A. Smock). Nebraska: Nebraska University Press.

Bleeker, Maaike; Sherman, Jon Foley, \& Nedelkopoulou, Eirini (Eds). (2015). Performance and Phenomenology. Traditions and Transformation. New York: Routledge. 
Bown, Nicola (Ed). (2007). Special Issue: Rethinking Victorian Sentimentality. Interdisciplinary Studies in the Long Nineteenth Century, 19(4), 187-194. https:// doi.org/10.16995/ntn.453

Brenkman, John. (2020). Mood and Trope: The Rhetoric and Poetics of Affect. Chicago: Chicago University Press.

Brown, Steven, \& Stenner, Paul. (2001). Being Affected: Spinoza and the Psychology of Emotion. International fournal of Group Tensions, 30(1), 81-105. https://doi.org/10.1023/A:1026658201222

Canning, Patricia, \& Whiteley, Sara (Eds.). (2017). Special Issue: Reader Response Research in Stylistics. Language and Literature, 26(2), 172-187. https://doi.org/ $\underline{10.1177 / 0963947017704724}$

Chen, Mel Y. (2012). Animacies: Biopolitics, Racial Mattering, and Queer Affect. Durham, NC: Duke University Press.

Clough, Patricia Ticineto. (2000). Comments on Setting Criteria for Experimental Writing. Qualitative Inquiry, 6(2), 278-291. https://doi.org/10.1177/107780040000600211

Clough, Patricia Ticineto. (2008). (De)Coding the Subject-in-Affect. Subjectivity, 23(1), 140-155. https://doi.org/10.1057/sub.2008.16

Clough, Patricia Ticineto. (2009). The New Empiricism. Affect and Sociological Method. European fournal of Social Theory, 12(1), 43-61. https://doi.org/10.1177/1368431008099643

Clough, Patricia Ticineto. (2018). The User Unconscious. Minneapolis: University of Minnesota Press.

Colebrook, Claire. (2005). Philosophy and Post-structuralist Theory. Edinburgh: Edinburgh University Press.

Cvetkovich, Ann. (2003). An Archive of Feelings: Trauma, Sexuality, and Lesbian Public Culture. Durham, NC: Duke University Press.

Cvetkovich, Ann. (2007). Public Feelings. South Atlantic Quarterly, 106(3), 459-468. https://doi.org/10.1215/00382876-2007-004

Cvetkovich, Ann. (2012). Depression: A Public Feeling. Durham, NC: Duke University Press.

Deleuze, Gilles. (1990/1992). Expressionism in Philosophy. New York: Zone Books.

Deleuze, Gilles, \& Guattari, Félix. (1991/1996). What is Philosophy? (Trans. H. Tomlinson, \& G. Burchell). New York: Columbia University Press.

Derrida, Jacques. (1976). Of Grammatology. (Trans. Gayatri Chakravorty Spivak). Baltimore: Johns Hopkins University Press.

Eng, David L. (2010). The Feeling of Kinship: Queer Liberalism and the Racialization of Intimacy. Durham, NC: Duke University Press.

Felski, Rita. (2015). The Limits of Critique. Chicago, IL: University of Chicago Press

Figlerowicz, Magdalena. (2012). Affect Theory Dossier: An Introduction. Qui Parle: Critical Humanities and Social Sciences, 20(2), 3-18.

https://doi.org/10.5250/quiparle.20.2.0003 
Figlerowicz, Magdalena. (2017). Spaces of Feeling: Affect and Awareness in Modernist Literature. Ithaca, NY: Cornell University Press.

Frank, Adam. (2014). Transferential Poetics. From Poe to Warhol. New York: The American Literatures Initiative.

Fritsch, Jonas, \& Markussen, Thomas (Eds). (2012). Exploring Affect in Interaction Design, Interaction-based Art and Digital Art. The Fibreculture fournal. Digital Media + Networks + Transdisciplinary Critique, 21, 1-18.

Goodman, Steve. (2010). Sonic Warfare: Sound, Affect and the Ecology of Fear. Cambridge, MA: MIT Press.

Gregg, Melissa, \& Seigworth, Gregory (Eds). (2010). The Affect Theory Reader. Durham: Duke University Press.

Hansen, Mark B. N. (2004). New Philosophy for New Media. Cambridge, MA: MIT Press.

Hansen, Mark B. N. (2006). Bodies in code: Interfaces with digital media. New York: Routledge.

Hansen, Mark B. N. (2015). Feed-forward: On the future of Twenty-first-century Media. Chicago: University of Chicago Press.

Haraway, Donna. (1989). Situated Knowledges: The Science Question in Feminism and the Privilege of Partial Perspective. Feminist Studies, 14(3), 575-599. https://doi.org/10.2307/3178066

Harman, Graham. (2002). Tool-being: Heidegger and the Metaphysics of Objects. Chicago: Open Court.

Hayles, Katherine. (1999). How We Became Posthuman. Virtual Bodies in Cybernetics, Literature, and Informatics. Chicago: The University of Chicago Press.

Hemmings, Clare. (2005). Invoking Affect. Cultural Theory and the Ontological Turn. Cultural Studies, 19(5), 548-567. https://doi.org/10.1080/09502380500365473

Hendler, Glenn. (2001). Public Sentiments: Structures of Feeling in Nineteenth-Century American Literature. Chapel Hill: The University of North Carolina Press.

Highmore, Ben. (2010) Bitter after Taste: Affect, Food, and Social Aesthetics. In Melissa Gregg \& Gregory Seigworth (Eds.), The Affect Theory Reader (pp. 118-137). Durham: Duke University Press.

Hogan, Patrick C. (2016). Affect Studies and Literary Criticism. Oxford Research Encyclopedia of Literature. https://doi.org/10.1093/acrefore/9780190201098.013.105

Houen, Alex (Ed.). (2011). Introduction: Affecting words. Textual Practice, 25(2), 215232. https://doi.org/10.1080/0950236x.2011.552288

Houser, Heather. (2014). Ecosickness in Contemporary US Fiction: Environment and Affect. New York: Columbia University Press.

Hurley, Erin (Ed.). (2014). Theatres of Affect. Toronto: Playwrights Canada Press, 2014.

Kant, Immanuel. (1790/1987). Critique of Judgement. Trans. Werner Pluhar. Cambridge: Hackett Publishing Company.

Karatzogianni, Athina, \& Kuntsman, Adi. (2012). Digital Cultures and the Politics of Emotion: Feelings, Affect and Technological Change. London: Palgrave Macmillan. 
Kassabian, Anahid. (2013). Ubiquitous Listening: Affect, Attention, and Distributed Subjectivity. Berkeley: University of California Press

Kwastek, Katja. (2013). Aesthetics of Interaction in Digital Art. Massachusetts: MIT Press.

Lara, Ali. (2017). Wine's Time: Duration, Attunement, and Diffraction. Subjectivity, 10(1), 104-122. https://doi.org/10.1057/s41286-016-0016-4

Lara, Ali, \& Enciso Domínguez, Giazú. (2013). El giro afectivo. Athenea Digital, 13(3), 101-119. https://doi.org/10.5565/rev/athenead/v13n3.1060

Lepecki, André. (2016). Singularities: Dance in the Age of Performance. New York: Routledge.

Love, Heather. (2007). Feeling Backward: Loss and the Politics of Queer History. Cambridge MA: Harvard University Press.

Macón, Cecilia. (2014). Género, afectos y política: Lauren Berlant y la irrupción de un dilema. Debate Feminista, 25(49), 163-186. https://doi.org/10.1016/s01889478(16)30009-3

Macón, Cecilia, \& Solana, Mariela. (2015). Pretérito indefinido: afectos y emociones en las aproximaciones al pasado. Buenos Aires: Título.

Malabou, Catherine. (2012). Following Generation. Qui Parle: Critical Humanities and Social Sciences, 20(2), 19-33. https://doi.org/10.5250/quiparle.20.2.0019

Manning, Erin, \& Massumi, Brian. (2014). Thought in the Act. Passages in the Ecology of Experience. Minneapolis: University of Minnesota Press.

Marculescu, Andreea, \& Morand Métivier, Charles-Louis (Eds.). (2018). Affective and Emotional Economies in Medieval and Early Modern Europe. New York: Palgrave Macmillan.

Massumi, Brian. (1995). The Autonomy of Affect. Cultural Critique, 31, 83-109. https://doi.org/10.2307/1354446

Massumi, Brian. (2002). Parables for the Virtual. Affect, Movement, Sensation. Durham, NC: Duke University Press.

Massumi, Brian. (2015). Politics of Affect. Cambridge, UK: Polity.

McKim, Joel. (2008, August 15). 'Of Microperception and Micropolitics' An Interview with Brian Massumi. INFLeXions, 3.

Morton, Timothy (2012a). From Modernity to the Anthropocene: Ecology and Art in the Age of Asymmetry. International Social Science fournal, 63(207-208), 39-51. https://doi.org/10.1111/issj.12014

Morton, Timothy. (2012b). An Object-Oriented Defense of Poetry. New Literary History, 43(2), 205-224. https://doi.org/10.1353/nlh.2012.0018

Morton, Timothy. (2013). Realist Magic: Objects, Ontology, Causality. Ann Arbor: Open Humanities Press.

Ngai, Sianne. (2005). Ugly Feelings. Cambridge, MA: Harvard University Press.

Ngai, Sianne. (2012). Our Aesthetic Categories. Zany, Cute, Interesting. Cambridge, MA: Harvard University Press. 
O’Sullivan, Simon. (2001). The Aesthetics of Affect. Thinking Art beyond Representation. Angelaki. Routledge, 6(3), 125-135. https://doi.org/10.1080/09697250120087987

O’Sullivan, Simon. (2006). Art Encounters Deleuze and Guattari. Thought Beyond Representation. New York: Palgrave Macmillan.

Paszkiewicz, Katarzyna (Ed.). (2016). Pensar el afecto desde la cultura y el arte. Thinking about Affect in Culture and Art. $452^{\circ} \mathrm{F}$ Revista de teoría de la literatura y literatura comparada, 14, 3-6.

Probyn, Elspeth. (2010). Writing Shame. In Melissa Gregg and Gregory Seigoworth (Eds.), The Affect Theory Reader (pp. 71-90). Durham: Duke University Press.

Reason, Matthew, \& Mølle Lindelof, Anja. (2017). Experiencing Liveness in Contemporary Performance: Interdisciplinary Perspectives. New York: Routledge.

Richardson, Michael. (2016). Gestures of Testimony. Torture, Trauma, and Affect in Literature. New York: Bloomsbury Academic.

Riley, Denise. (2005). Impersonal Passions. Language as Affect. Durham, NC: Duke University Press.

Sedgwick, Eve, \& Frank, Adam. (1995). Shame in the Cybernetic Fold. Reading Silvan Tomkins. Critical Inquiry, 21(2), 496-522. https://doi.org/10.1086/448761

Shaviro, Steven. (1990). Passion \& Excess: Blanchot, Bataille, and Literary Theory. Tallahassee: Florida State University Press.

Shaviro, Steven. (2009). Without Criteria: Kant, Whitehead, Deleuze, and Aesthetics. Cambridge, MA: MIT Press.

Shaviro, Steven. (2010). Post Cinematic Affect. Ropley: John Hunt Publishing.

Shaviro, Steven. (2015). Discognition. London: Repeater Books.

Sheller, Mimi. (2015). Vital Methodologies. Live Methods, Mobile Art, and ResearchCreation. In Phillip Vannini, (Ed.), Non-Representational Methodologies. ReEnvisioning Research (pp. 130-144), New York: Routledge.

Spinoza, Baruch. (1677/1985). The Collected Works of Spinoza. Ed. and trans. Edwin Curley. (Vol. 1). Princeton: Princeton University Press.

Smith, Rachel Greenwald. (2011). Postmodernism and the Affective Turn. TwentiethCentury Literature, 57(3, 4), 423-446. https://doi.org/10.1215/0041462x-2011$\underline{4008}$

Smith, Rachel Greenwald. (2015). Affect and American Literature in the Age of Neoliberalism. Cambridge, MA: Cambridge University Press.

Somers-Hall, Henry. (2012). Hegel, Deleuze, and the Critique of Representation. Dialectics of Negation and Diference. Albany: State University of New York.

Stewart, Kathleen. (2007). Ordinary Affects. Durham, NC: Duke University Press.

Stewart, Kathleen. (2015). New England Red. In Phillip Vannini (Ed.), NonRepresentational Methodologies. Re-Envisioning Research. New York: Routledge.

Taylor, Julie (Ed.) (2015). Modernism and Affect. Edinburgh: Edinburgh University Press. 
Terada, Rei. (2001). Feeling in Theory. Emotion after the "Death of the Subject." Cambridge, Mass.: Harvard University Press.

Thrailkill, Jane F. (2007). Affecting Fictions: Mind, Body, and Emotion in American Literary Realism. Cambridge, Mass.: Harvard University Press.

Thompson, Marie. (2017). Beyond Unwanted Sound: Noise, Affect and Aesthetic Moralism. New York: Bloomsbury.

Thomassen, Lasse. (2017). Poststructuralism and Representation. Political Studies Association, 15(4), 539-550. https://doi.org/10.1177/1478929917712932

Thrift, Nigel. (2007). Non-representational Theory. Space, Politics, Affect. New York: Routledge.

Tomkins, Silvan S. (1962). Affect, Imagery, Consciousness. New York: Springer Pub. Vannini, Phillip (Ed.). (2015). Non-Representational Methodologies. Re-Envisioning Research. New York: Routledge.

Vermeulen, Pieter. (2015). Contemporary Literature and the End of the Novel: Creature, Affect, Form. New York: Palgrave Macmillan.

Wehrs, Donald R., \& Blake, Thomas (Eds). (2017). The Palgrave Handbook of Affect Studies and Textual Criticism. New York: Palgrave Macmillan.

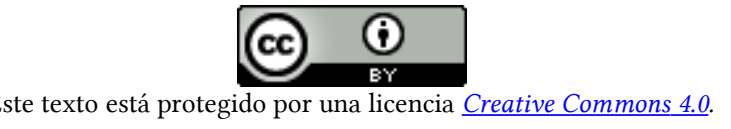

Usted es libre para Compartir — copiar y redistribuir el material en cualquier medio o formato- y Adaptar el documento - remezclar, transformar y crear a partir del material - para cualquier propósito, incluso comercialmente, siempre que cumpla la condición de:

Atribución: Usted debe reconocer el crédito de una obra de manera adecuada, proporcionar un enlace a la licencia, e indicar si se han realizado cambios . Puede hacerlo en cualquier forma razonable, pero no de forma tal que sugiera que tiene el apoyo del licenciante o lo recibe por el uso que hace. 